\title{
IN VITRO WEAR OF TEN UNIVERSAL COMPOSITES
}

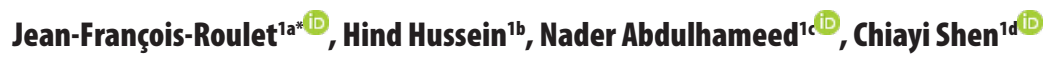 \\ 'Department of Restorative Dental Science, Center of Dental Biomaterials College of Dentistry \\ University of Florida, Gainesville, FL32610, USA \\ ${ }^{a}$ Dr. med.dent, Dr. hc, Professor \\ ${ }^{b} D D S$ \\ DDS \\ ${ }^{\mathrm{D} D M D}, \mathrm{PhD}$
}

ABSTRACT

DOI: https://doi.org/10.25241/stomaeduj.2019.6(2).art.1

\begin{tabular}{|c|c|}
\hline 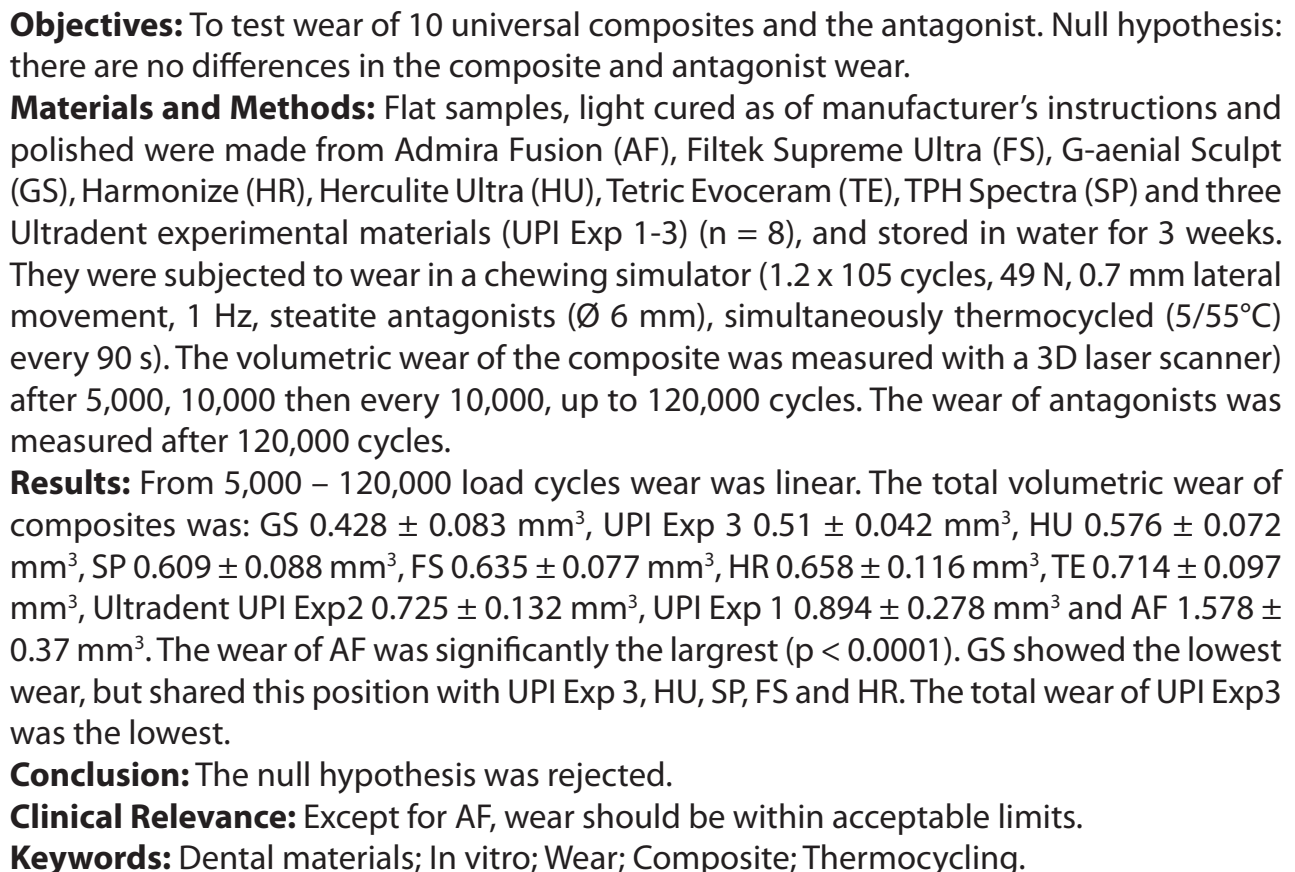 & 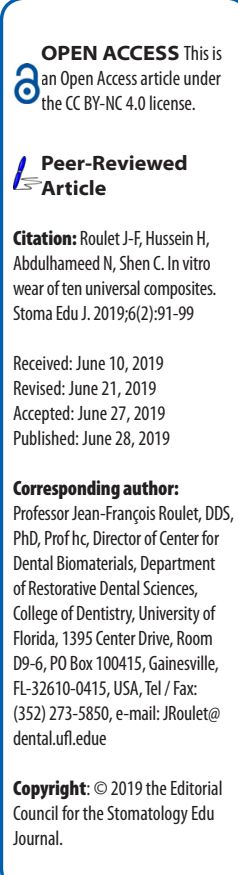 \\
\hline
\end{tabular}

\section{Introduction}

Since their invention in the 1950s [1-3], composites have been continuously improved, however without abandoning their basic concepts. Over the years it became very obvious that the fillers used had the greatest influence on their physical and mechanical properties [4]. The fillers determine the mechanical properties, they reduce the polymerization shrinkage, the filler selection may optimize wear behavior, they influence the optical properties (translucency) and may enhance the radiopacity. Furthermore, the surface characteristics and thus the polishability depend on the fillers, with consequences for the handling properties and finally the aesthetic appearance of a composite restoration [5]. Historically quartz was first replaced by a variety of different glasses, followed by socalled microfillers (Aerosil, fumed silica), which were first introduced into a resin matrix, which was polymerized and ground into powder. This filler was also referred to as prepolymerized particles [68] which were incorporated into a matrix filled with fumed silica. Optimal X-ray contrast was achieved by ytterbium trifluoride filler [9]. In parallel with the improvement in glass milling technology, it was also recognized that optimal "intelligent" filler particle size distribution reduced the resin content, which had a positive effect on polymerization shrinkage [8]. Using flame spray pyrolysis [10] silica based nanoparticles over a wide range of size could be produced. Furthermore, it was possible to create spherical mixed oxide (ytterbium oxide and silica) nanoparticles that matched the refractive index of the resin mix (1.53) resulting in radiopaque composites with high translucency [11]. Finally, composites based solely on nanoparticle technology were introduced. However, the true single particle nanofillers are dispersed in a matrix, which is filled with so-called nanoclusters, with dimensions far away from the nano range [12]. Being aggregated nanoparticles, the clusters lost many advantages of the nanotechnology. The changes outlined above are reflected in a multitude of composite classifications based on their fillers $[4,6,7,13-17]$.

Clinical Studies of early composites placed in posterior teeth have revealed substantial wear [18]. With the improvement of the filler technology as described above, the longevity of posterior composite restorations can be excellent. The survival behavior of restorations is shown best with Kaplan- 
ITable 1. Materials used incl. filler composition.

\begin{tabular}{|c|c|c|c|c|c|}
\hline Name & Color & Type & Filler & Manufacturer & Batch \# \\
\hline $\begin{array}{l}\text { Admira Fusion } \\
\text { (AF) }\end{array}$ & $\mathrm{A} 2$ & $\begin{array}{l}\text { Universal } \\
\text { Nanohybrid- } \\
\text { Ormocer }\end{array}$ & $\begin{array}{l}84 \% \text { w/w inorganic fillers: } \mathrm{SiO}_{2} \text { glass and } \\
\text { nanoparticles }\end{array}$ & $\begin{array}{l}\text { Voco GmbH, } \\
\text { Cuxhaven, Germany }\end{array}$ & 1638273 \\
\hline $\begin{array}{l}\text { Filtek Supreme } \\
\text { Ultra (FS) }\end{array}$ & $\begin{array}{l}\text { A2 } \\
\text { Enamel }\end{array}$ & Ultra Universal & $\begin{array}{l}\text { Agglomerated zirconia/silica cluster, } \\
\text { average cluster size } 0.6-20 \mu \mathrm{m} \text {. Non } \\
\text { agglomerated/non aggregated silica } \\
\text { filler } 20 \mathrm{~nm} \text {, and zirconia filler } 4 \text { - } 11 \mathrm{~nm} \text {. } \\
\text { Total filler } 72.5 \% \mathrm{w} / \mathrm{w}\end{array}$ & $\begin{array}{l}\text { 3M Espe St. Paul, MN, } \\
\text { USA }\end{array}$ & N808359 \\
\hline $\begin{array}{l}\text { G-aenial } \\
\text { Sculpt (GS) }\end{array}$ & $\begin{array}{l}\text { Adult } \\
\text { Enamel }\end{array}$ & $\begin{array}{l}\text { Universal } \\
\text { Nanohybrid } \\
\text { Compactable }\end{array}$ & $\begin{array}{l}\text { Uniform nano-filler dispersion } \\
\text { technology Barium glass } 300 \mathrm{~nm}\end{array}$ & $\begin{array}{l}\text { GC Corp, Tokyo, } \\
\text { Japan }\end{array}$ & 1506111 \\
\hline $\begin{array}{l}\text { Harmonize } \\
(\mathrm{HR})\end{array}$ & $\begin{array}{l}\mathrm{A} 2 \mathrm{E} \\
\text { Enamel }\end{array}$ & $\begin{array}{l}\text { Nanohybrid } \\
\text { Universal }\end{array}$ & $\begin{array}{l}\text { Barium glass } 400 \mathrm{~nm} \text {, Silica and zirconia } \\
\text { nanoparticles }>5 \mathrm{~nm} \text {. Average particle } \\
\text { size } 50 \mathrm{~nm} \text { Total filler } 81 \% \mathrm{w} / \mathrm{w}\end{array}$ & $\begin{array}{l}\text { Kerr Co., Orange, CA, } \\
\text { USA }\end{array}$ & 6173894 \\
\hline $\begin{array}{l}\text { Herculite Ultra } \\
(\mathrm{HU})\end{array}$ & $\begin{array}{l}\text { A2 } \\
\text { Enamel }\end{array}$ & Nanohybrid & $\begin{array}{l}\text { Ba-glass filler } 0.4 \mu \mathrm{m} \text {, Prepolymerized } \\
\text { Filler, Silica nanofiller, } 20-50 \mathrm{~nm} \text { Total } \\
\text { filler } 78 \% \mathrm{w} / \mathrm{w}\end{array}$ & Kerr Co., Orange, CA & 6037221 \\
\hline $\begin{array}{l}\text { Tetric } \\
\text { EvoCeram (TE) }\end{array}$ & $\begin{array}{l}\text { A2 } \\
\text { Enamel }\end{array}$ & $\begin{array}{l}\text { Universal } \\
\text { Composite }\end{array}$ & $\begin{array}{l}\text { Ba-Al-Silicate glass } 0.4 \text { and } 0.7 \mu \mathrm{m}, \\
\text { Yterbuimfluoride, Mixed Oxyde } 160 \mathrm{~nm} \text {, } \\
\text { Isofiller (Prepolymerized Filler), } \mathrm{SiO}_{2} 40 \\
\mathrm{~nm}\end{array}$ & $\begin{array}{l}\text { Ivoclar Vivadent, } \\
\text { Schaan Liechtenstein }\end{array}$ & V27337 \\
\hline $\begin{array}{l}\text { TPH Spectra } \\
\text { (SP) }\end{array}$ & $\mathrm{A} 2 \mathrm{HV}$ & $\begin{array}{l}\text { Universal } \\
\text { Composite }\end{array}$ & $\begin{array}{l}\text { Ba-Al-borosilicate glass, Ba-B-F-al- } \\
\text { silicate glass, } \mathrm{SiO}_{2} \text {. Total filler } 77.2 \% \mathrm{w} / \mathrm{w}\end{array}$ & $\begin{array}{l}\text { Dentsply Caulk, } \\
\text { Milford, DE, USA }\end{array}$ & 160401 \\
\hline $\begin{array}{l}\text { Ultradent UPI } \\
\text { Exp } 1\end{array}$ & $\begin{array}{l}\text { A2 } \\
\text { Dentin }\end{array}$ & $\begin{array}{l}\text { Universal } \\
\text { Composite }\end{array}$ & $\begin{array}{l}\text { Total filler: } 68 \% \mathrm{v} / \mathrm{v} \\
\text { zirconia-silica glass ceramic and } 20 \\
\text { nanometer silica }\end{array}$ & $\begin{array}{l}\text { Ultradent Products } \\
\text { Inc., South Jordan, } \\
\text { UT, USA }\end{array}$ & RTO0E00A \\
\hline $\begin{array}{l}\text { Ultradent UPI } \\
\text { Exp } 2\end{array}$ & Enamel & $\begin{array}{l}\text { Universal } \\
\text { Composite }\end{array}$ & $\begin{array}{l}\text { Total filler: } 56 \% \mathrm{v} / \mathrm{v} \\
\text { zirconia-silica glass ceramic and } 20 \\
\text { nanometer silica }\end{array}$ & $\begin{array}{l}\text { Ultradent Products } \\
\text { Inc., South Jordan, } \\
\text { UT, USA }\end{array}$ & SW20E15B \\
\hline $\begin{array}{l}\text { Ultradent UPI } \\
\text { Exp } 3\end{array}$ & Enamel & $\begin{array}{l}\text { Nano-hybrid } \\
\text { Composite }\end{array}$ & $\begin{array}{l}\text { Total filler: } 80.9 \% \mathrm{w} / \mathrm{w} \\
\text { barium borosilicate glass filler. Average } \\
\text { particle size is } 0.89 \text { micrometers }\end{array}$ & $\begin{array}{l}\text { Ultradent Products } \\
\text { Inc., South Jordan, } \\
\text { UT, USA }\end{array}$ & 20E15B \\
\hline
\end{tabular}

Meier survival statistics. However, with those the comparison of different studies is difficult. Therefore, most authors report the \% survival of restorations after a given time (e.g. 5 or 10 years). For direct comparisons these can be converted into \%-annual failure rates (AFR). On the one side, clinical long-term studies show annual failure rates (AFR) between $0.1 \%$ and $0.67 \%$ after 10 years [19], $1.1 \%$ after 30 years [20], and $1.5 / 2.2 \%$ after 22 years [21]. On the other hand, higher AFRs have been reported. In a systematic review Opdam et al [22] reported AFRs of $1.8 \%$ (5 years) and $2.4 \%$ (10 years). However, when discriminating between high caries risk and low caries risk, the respective numbers were $3.2 \%$ and $4.6 \%$ for high caries risk and $1.2 \%$ and $1.6 \%$ for low caries risk respectively. A significant material effect could be found as well. In another review article, Demarco et al [23] reported AFRs between $0 \%$ and $8.6 \%$, which may allow the question that the dentist may be a significant cofactor. Hickel and Manhart [24] found similar results. They reported AFRs between $0 \%$ and $9 \%$. Only 3 out of 24 studies reported wear. The authors concluded that the factors influencing longevity of restorations were the patient, the dentist and the material. In an extensive review about the longevity of restorations Manhart et al [25] found that over time composites have significantly improved. For direct restorations they found in publications before 1990 an AFR of 4.2, while in papers published after 1990 the AFR was 2.0. In the past, composites were specifically developed for a specific indication (anterior or posterior restorations), based on their aesthetic or wear behavior. Contemporary composite materials that have reached a high degree of maturity, are complex constructs [26], and well accepted by the profession. They are designed as universal composites suitable for the application in the anterior and posterior segment. Furthermore, with the improved knowledge of application techniques composites are used for larger restorations as in the past, which brings back the question if composites are sufficiently wear resistant to carry occlusal load. Composite restorations should have similar wear to enamel so restorations behave similarly to teeth. This is important, especially when the indication of 
I Table 2. Light curing parameters according to manufacturers' instructions for use.

\begin{tabular}{lccc}
\hline Material & $\begin{array}{c}\text { Curing } \\
\text { time } \\
(\mathbf{s})\end{array}$ & $\begin{array}{c}\text { Exitance } \\
\text { irradiation } \\
\left(\mathbf{m W} / \mathbf{c m}^{2}\right)\end{array}$ & $\begin{array}{c}\text { Radiant } \\
\text { exposure } \\
\left(\mathbf{J} / \mathbf{c m}^{2}\right)\end{array}$ \\
\hline Admira Fusion & 20 & 1170 & 23.40 \\
$\begin{array}{l}\text { Filtek Supreme } \\
\text { Ultra }\end{array}$ & 10 & 1170 & 11.70 \\
G-aenial Sculpt & 10 & 1170 & 11.70 \\
Harmonize & 10 & 1170 & 11.70 \\
Herculite Ultra & 10 & 1170 & 11.70 \\
Tetric EvoCeram & 10 & 1170 & 11.70 \\
TPH Spectra & 10 & 1170 & 11.70 \\
UPI Exp 1 & 20 & 1170 & 23.40 \\
UPI EXP 2 & 20 & 1170 & 23.40 \\
UPI EXP 3 & 20 & 1170 & 23.40 \\
\hline
\end{tabular}

direct composite restorations includes the buildup of missing cusps. Then the occlusion cannot be supported by natural tooth structure (enamel). Therefore, the aim of this study was to test the wear characteristics of three experimental universal composites as compared to seven commercially available contemporary composites with different filler-compositions. The null hypothesis was that there are no differences in the composite wear as well as in the wear of the antagonists.

\section{Materials and Methods}

The Universal composite materials used are described in Table 1.

Eighty aluminum sample holders (inner $\varnothing 8 \mathrm{~mm}$ depth $1.5 \mathrm{~mm}$ ) were modified to have mechanical retention, then one coat of universal bond (Monobond Plus, Ivoclar Vivadent, Liechtenstein) was added and left for $60 \mathrm{~s}$, followed by air blasting to evaporate the solvent. Then one coat of adhesive (Optibond FL 2, Kerr, CA, USA) was applied and light cured according to the manufacturers' instructions using a Valo Grand (Ultradent Products, South Jordan, UT, USA) at standard mode delivering $1170 \mathrm{~mW} / \mathrm{cm}^{2}$, measured with a Bluephase Meter II (Ivoclar Vivadent, Liechtenstein). The composites were filled into the sample holders in one increment, then the top surface was flattened with a Mylar ${ }^{\otimes}$ matrix band and the composites were light cured with a Valo Grand in contact with the matrix band according to the composites manufacturers' instructions (Table 2).

The composite surfaces where finished and polished by using (Sof-Lex Disks, 3M, MN, USA), light orange disc for finishing and yellow disc for polishing for 10$15 \mathrm{~s}$, and the final gloss was obtained with Astropl silicon polishers (Ivoclar Vivadent, Liechtenstein). All samples were stored in distilled water for 3 weeks at $37^{\circ} \mathrm{C}$. Steatite balls $(\varnothing 6 \mathrm{~mm}$ ) mounted into aluminum
Table 3. Settings of Chewing Simulator.

\begin{tabular}{r|l} 
Load & $5 \mathrm{~kg}$ \\
Upstroke & $2 \mathrm{~mm}$ \\
Downstroke & $1 \mathrm{~mm}$ \\
$\begin{array}{r}\text { Horizontal } \\
\text { movement }\end{array}$ & $0.7 \mathrm{~mm}$ \\
Upward speed & $60 \mathrm{~mm} / \mathrm{s}$ \\
Downward speed & $60 \mathrm{~mm} / \mathrm{s}$ \\
Horizontal speed & $40 \mathrm{~mm} / \mathrm{s}$ \\
Frequency & $1 \mathrm{~Hz}$ \\
$5^{\circ} \mathrm{C}-55^{\circ} \mathrm{C} 30 \mathrm{~s} \mathrm{holding} \mathrm{time,}$ \\
transfer time $15 \mathrm{~s}$, total cycle $90 \mathrm{~s}$ \\
Thermocycling
\end{tabular}

holders with composite were used as antagonists. One antagonist per sample $(n=64)$ was used and discarded after finishing all cycles.

The chewing simulator was run according to the parameters listed in Table 3. The specimens were simultaneously thermocycled $\left(5 / 55^{\circ} \mathrm{C}\right)$ every $90 \mathrm{~s}$. This resulted in 120,000 mechanical cycles and 1333 thermal cycles as a total. After 5,000, 10,000, 20,000, 40,000, $60,000,80,000,100,000$, and 120,000 load cycles, Polyvinylsiloxane impressions (Virtual Extra light body, Fast set Wash material, Ivoclar Vivadent, Liechtenstein) using small cylindrical PVC trays were taken from the samples. From the antagonists, impressions were taken before the experiment and after 120,000 cycles (end point of the experiment). All impressions were cast using a dental stone (Micro stone, Whip Mix Co, Louisville, KY, USA).

The stone models were then scanned with a 3D laser scanner, Laserscanner LAS-20 (SD Mechatronik GmbH, Feldkirchen-Westerham, Germany). By using geometric software Geomagic control 2014 (3D Systems, Inc, USA), the scanned data were used to measure the wear of the samples after each round. The flat surface of the sample was used as a reference plain and the wear was calculated as the volume of the wear facet relative to the reference plane. The wear of the steatite antagonists was measured as well in volume loss comparing the initial with the final model. Data were analyzed using ANOVA, linear regression and the Tukey test.

From every group selected samples were dried in ambient air, sputtered with AuPd, and SEM, MIRA3 (TESCAN, PA, USA) pictures at magnifications up to 3200 were taken from the worn surfaces (composite and antagonist) in order to see the wear patterns and possible breakdowns in the surfaces.

\section{Results}

As expected, from 10,000 - 120,000 load cycles we found a statistically significant linear correlation of wear with chewing cycle (Fig. 1) The ANOVA showed significant differences $(p<0.0001$ ). After 120,000 cycles, the total wear of composite in volume varied from $0.428 \mathrm{~mm}^{3}$ to $1.578 \mathrm{~mm}^{3}$.

The volumetric wear for every material after 120,000 
Table 4. Wear of composites in $\mathrm{mm}^{3}$ after $120 \mathrm{~K}$ cycles. Same letter = same statistical group $(p<0.05)$.

\begin{tabular}{lll}
\hline Material & Mean \pm SD & $\begin{array}{l}\text { Statistical } \\
\text { group }\end{array}$ \\
\hline Admira Fusion & $1.578 \pm 0.369 \mathrm{~mm}^{3}$ & $\mathrm{~A}$ \\
UPI Exp 1 & $0.894 \pm 0.278 \mathrm{~mm}^{3}$ & B \\
UPI Exp 2 & $0.725 \pm 0.132 \mathrm{~mm}^{3}$ & BC \\
Tetric EvoCeram & $0.714 \pm 0.097 \mathrm{~mm}^{3}$ & BC \\
Harmonize & $0.658 \pm 0.116 \mathrm{~mm}^{3}$ & BCD \\
Filtek Supreme Ultra & $0.635 \pm 0.077 \mathrm{~mm}^{3}$ & BCD \\
TPH Spectra & $0.609 \pm 0.088 \mathrm{~mm}^{3}$ & $\mathrm{CD}$ \\
Herculite Ultra & $0.576 \pm 0.072 \mathrm{~mm}^{3}$ & $\mathrm{CD}$ \\
UPI Exp 3 & $0.510 \pm 0.042 \mathrm{~mm}^{3}$ & $\mathrm{CD}$ \\
G-aenial Sculpt & $0.428 \pm 0.083 \mathrm{~mm}^{3}$ & D \\
\hline
\end{tabular}

Table 5. Wear of antagonists in $\mathrm{mm}^{3}$ generated by the different composites tested after $120 \mathrm{~K}$ cycles. Same letter $=$ same statistical group $(p<0.05)$.

\begin{tabular}{lll}
\hline Material & mean \pm SD & $\begin{array}{l}\text { Statistical } \\
\text { group }\end{array}$ \\
\hline G-aenial Sculpt & $0.290 \pm 0.023 \mathrm{~mm}^{3}$ & $\mathrm{~A}$ \\
Herculite Ultra & $0.231 \pm 0.024 \mathrm{~mm}^{3}$ & B \\
UPI Exp 2 & $0.210 \pm 0.024 \mathrm{~mm}^{3}$ & BC \\
Harmonize & $0.206 \pm 0.025 \mathrm{~mm}^{3}$ & BC \\
TPH Spectra & $0.175 \pm 0.018 \mathrm{~mm}^{3}$ & $\mathrm{C}$ \\
UPI Exp 3 & $0.130 \pm 0.037 \mathrm{~mm}^{3}$ & D \\
Tetric EvoCeram & $0.129 \pm 0.028 \mathrm{~mm}^{3}$ & D \\
UPI Exp 1 & $0.121 \pm 0.026 \mathrm{~mm}^{3}$ & D \\
Filtek Supreme Ultra & $0.113 \pm 0.017 \mathrm{~mm}^{3}$ & D \\
Admira Fusion & $0.100 \pm 0.017 \mathrm{~mm}^{3}$ & D \\
\hline
\end{tabular}

load cycles is shown in Table 4. The different composites created significantly different wear of the steatite antagonists $(p<0.05)$ (Table 5 and Fig. 2). Note that AF had significantly more wear than all other materials tested. GS showed the least wear; however, it shared this position with UPI Exp3, HU, SP, FS and HR. Since most composites wear in a similar way, there is a lot of overlap between $0.6 \mathrm{~mm}^{3}$ and $0.9 \mathrm{~mm}^{3}$ volume loss.

In general, the antagonist wear was a fraction of the composite wear and as a trend, materials which were worn a lot, produced the least antagonist wear, as seen with AF. On the other side, the material that showed the least wear (GS), was the most aggressive against the antagonist. When looking at wear as a system, then the total wear ( $\Sigma$ composite wear + antagonist wear) is of interest Fig. 3). Here the ranking was similar to the one of composite wear. However, UPI Exp 3 due to its very low antagonist wear ended up having the least total wear.

Some selected SEMs are shown in Figs 5-11. The composites mostly revealed the filler structure at high magnification (Figs 4-9), while the antagonists were either smooth or showed various degrees of

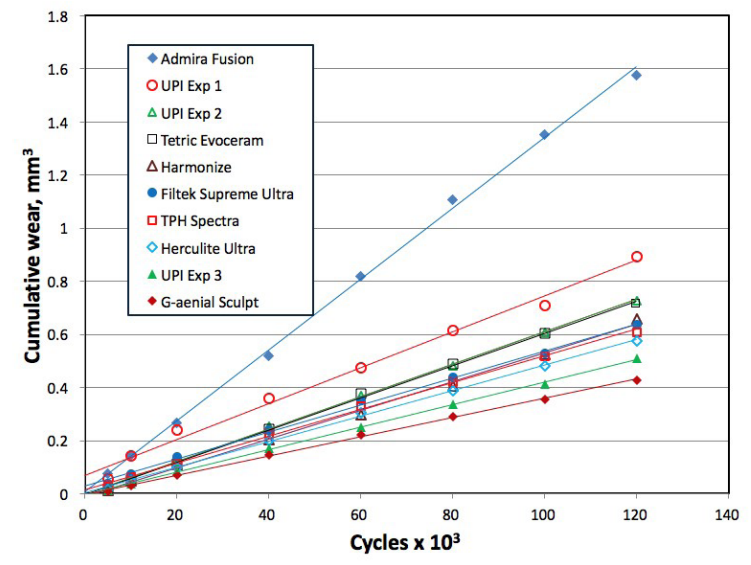

Figure 1. Cumulative wear of ten composites up to 120,000 load cycles. $(p<0.0001)$.

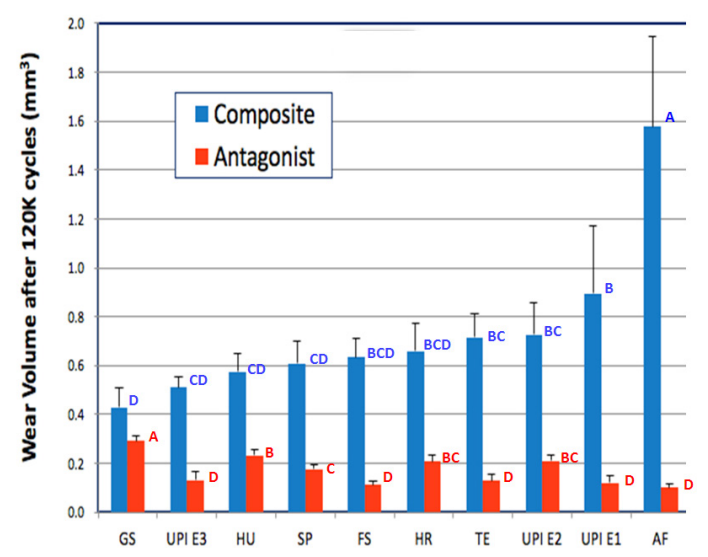

Figure 2. Wear volume of ten composites and the corresponding antagonists after 120,000 load cycles. Blue letters show same statistical group for composites, red letter for antagonists $(p<0.05)$. AF = Admira Fusion, FS $=$ Filtek Supreme, $\mathrm{GS}=\mathrm{G}$-aenial Sculpt, $\mathrm{HR}=$ Harmonize, $\mathrm{HU}=$ Herculite Ultra, TE = Tetric Evoceram, SP = TPH Spectra, UPI Exp 1-3 = Ultradent experimental composites.

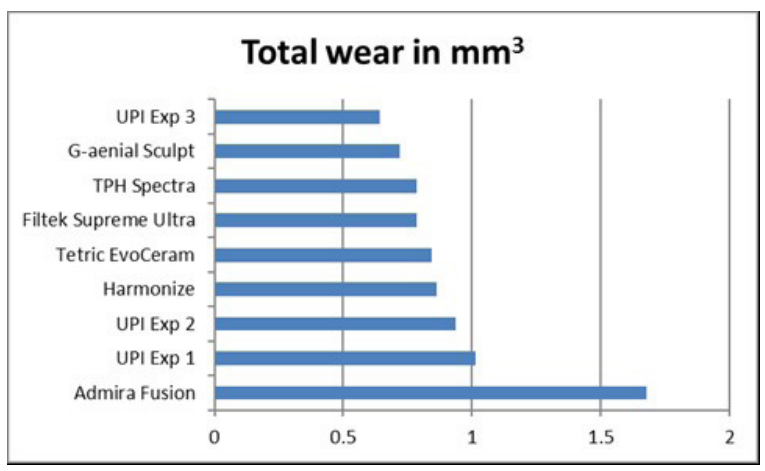

Figure 3. Total wear ( $\Sigma$ of composite + antagonist wear) in $\mathrm{mm}^{3}$.

scratches. Furthermore, pores were visible as well (Figs. 10 and 11).

\section{Discussion}

The seven commercial universal composites represent a selection of widely used materials. The three experimental materials were formulations of composites to be placed in the same market segment. All composites were light cured according to manufacturer's recommendations which reflects the condition of their clinical use. As can be seen in Table 2 the radiant exposure was 


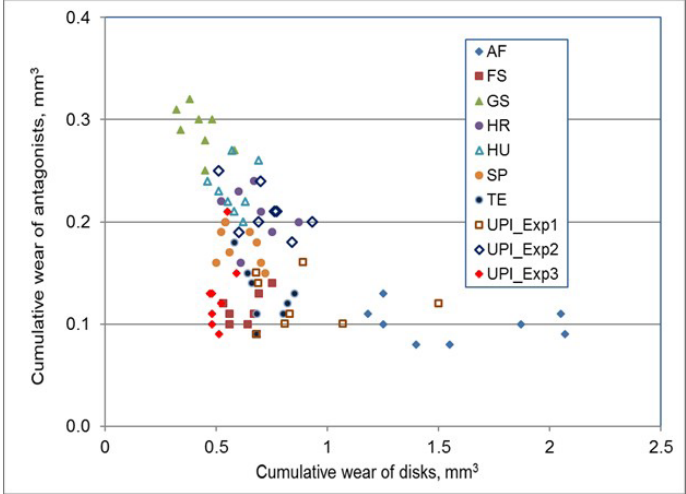

Figure 4. Cumulative wear of composites vs cumulative wear of Antagonists. AF = Admira Fusion, $\mathrm{FS}=$ Filtek Supreme, $\mathrm{GS}=\mathrm{G}$-aenial Sculpt, $\mathrm{HR}=$ Harmonize, $\mathrm{HU}=$ Herculite Ultra, $\mathrm{TE}=$ Tetric Evoceram, SP = TPH Spectra, UPI Exp 1-3 = Ultradent experimental composites.

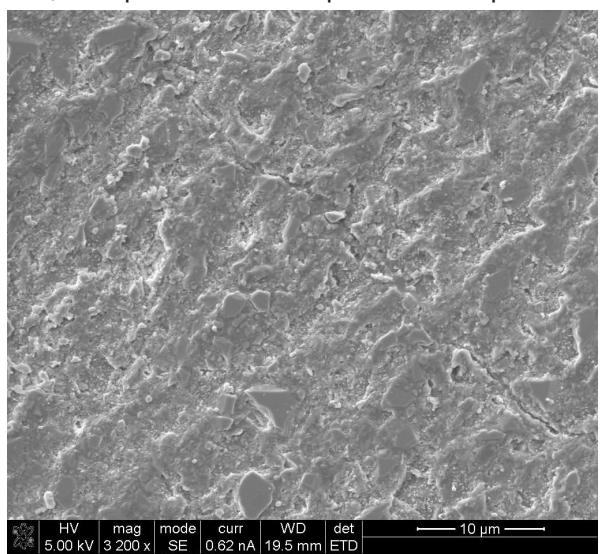

IFigure 5. Worn surface of AF. Note the sharp filler particles and the fracture line. SEM 3200 (AF1 011).

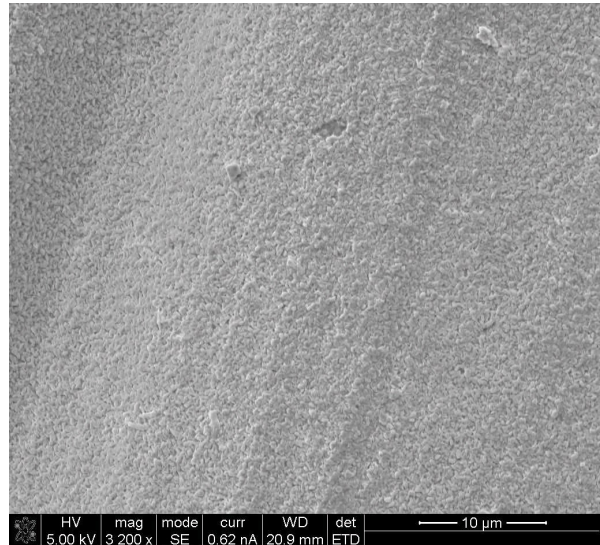

IFigure 6. Worn surface of GS. Note the fine granular surface. SEM 3200x (GS2-016).

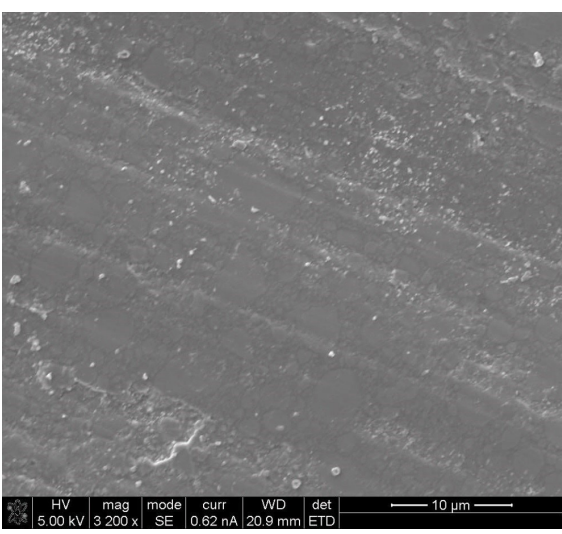

IFigure 7 Worn surface of UPI Exp 1 Note the filler particles that are well integrated SEM 3200x (MO1-014).

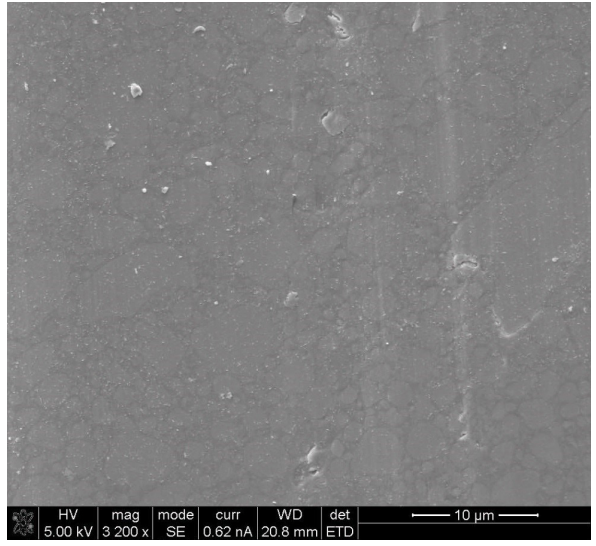

IFigure 8. Worn surface of UPI Exp2. Note the larger particles as compared to the ones in Fig 6 (M006).

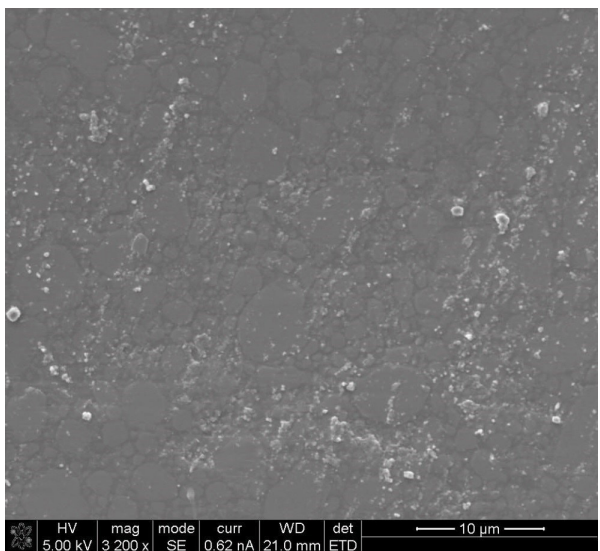

Figure 9. Worn surface of UPI Exp 3. Note the densly packed spherical particles of various sizes. (Mu2-15).

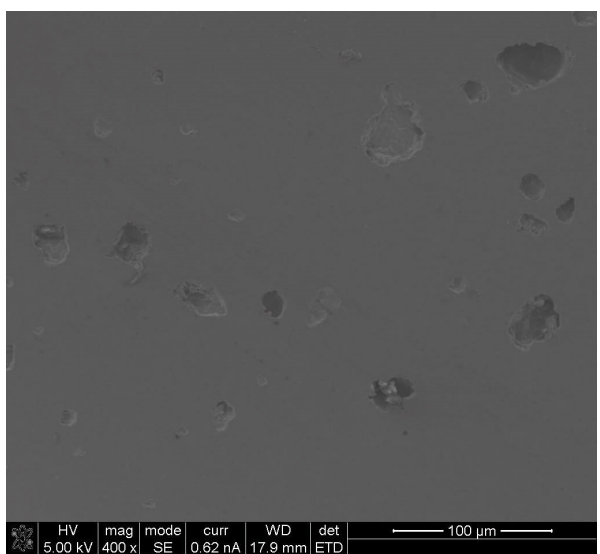

Figure 10. Antagonist worn by AF. Note the smooth surface and the pores SEM 400x. (AfAnt 004).

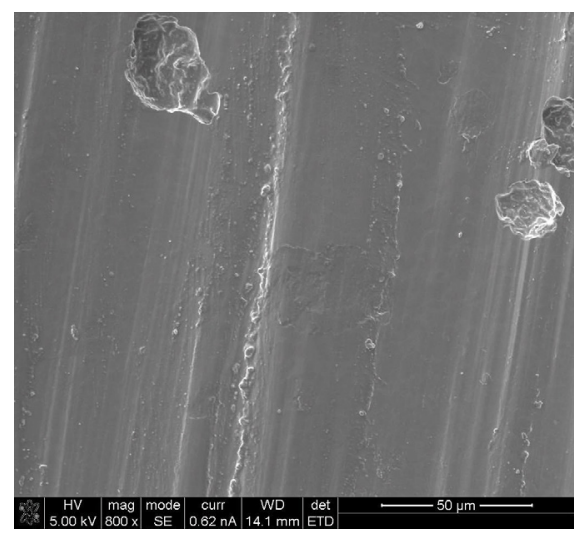

Figure 11. Antagonist surface worn by GS. Note the pores and the scratches. (GS2 Ant 004). 
between 11.7 and $23.4 \mathrm{~J} / \mathrm{cm}^{2}$, which is within the recommendations found in the literature to cure 2 $\mathrm{mm}$ depth of composite $[27,28]$.

Wear is a complex process. Therefore, there is no specific standard for testing wear of dental restorative materials. Especially in vitro, it is difficult to completely mimic the clinical situation. The various in vitro wear simulating machines use different approaches; recently, however, twobody wear machines with a sliding component and preferably computer-controlled forces and movements have been preferred [29]. Since every wear tester uses a different theoretical model [29], different antagonists are used in terms of material, shape and dimensions [30-35]. In the present work, spherical steatite antagonists ( $\varnothing 6 \mathrm{~mm}$ ) were used because of their hardness, reproducibility, the standard shape similar to a molar cusp, and the easy availability. It was deliberately decided not to use enamel as antagonists, due to variability in mechanical properties and shape. Attempts to grind natural cusp tips into a standard shape have revealed additional defects which would contribute to the variability of the expected results. In addition, most Mechatronics chewing simulator users use steatite antagonists, allowing comparisons with other studies. For the operation of the chewing simulator standard parameters as recommended by the manufacturer were used [36]. Therefore, our data are comparable to those of the Ivoclar Vivadent group in Schaan [26]. The Ivoclar protocol uses standardized Empress (leucite ceramics) antagonists that are in the shape of a molar cusp, while in the present experiment spherical steatite antagonists were used, which may explain the slightly different findings.

The wear values obtained with similar composite materials in a previous experiment [37] were approximately twice that of those in the present study using the same chewing simulator. This difference can be explained by the different chewing force [37]. In the present experiment, a load of 49 $\mathrm{N}$ was used, while in the previous experiment the load was $59 \mathrm{~N}$, which seems to be too much since fractures of the same samples had occurred. It is difficult to determine the actual chewing force in vivo under function. Literature data show a large variation $(20-120 \mathrm{~N})$. The decision to use $49 \mathrm{~N}$ was based on a publication by Gibbs et al. [38], where 49 $\mathrm{N}$ were found to be the average chewing force under normal function.

A laser scanner was used to measure wear facets. Heintze et al. [39] have shown that there is no significant difference between a mechanical or optical profilometer and a laser scanner.

For the present study, almost the same method was used as in previous studies [36,37]. The difference was that in the Matias study, the composite samples and the antagonists were directly scanned, while in the present study we chose to use hard plaster replicas. The reason for this was that when we scanned directly facets in polished, flat composite or ceramic surfaces and analyzed them with the Geomagic software, we found distortions in the flat surface at the transition to the facet [40]. In addition,
Table 6. Wear rate in $\times 10^{-6} \mathrm{~mm}^{3} /$ cycle of the tested materials. Same letter $=$ means same statistical group $(p<0.05)$

\begin{tabular}{lll}
\hline Material & mean \pm SD & $\begin{array}{l}\text { Statistical } \\
\text { group }\end{array}$ \\
\hline Admira Fusion & $13.33 \pm 3.24$ & $\mathrm{~A}$ \\
UPI Exp 1 & $6.77 \pm 1.83$ & $\mathrm{~B}$ \\
UPI Exp 2 & $6.11 \pm 1.15$ & $\mathrm{BC}$ \\
Tetric EvoCeram & $6.09 \pm 0.95$ & $\mathrm{BC}$ \\
Harmonize & $5.40 \pm 1.00$ & $\mathrm{BCD}$ \\
Filtek Supreme Ultra & $5.1 \pm 0.72$ & $\mathrm{BCD}$ \\
TPH Spectra & $5.04 \pm 0.74$ & $\mathrm{CD}$ \\
Herculite Ultra & $5.40 \pm 0.54$ & $\mathrm{CD}$ \\
UPI Exp 3 & $4.26 \pm 0.49$ & $\mathrm{CD}$ \\
G-aenial Sculpt & $3.26 \pm 0.73$ & $\mathrm{D}$ \\
\hline
\end{tabular}

we had two evaluators who outlined the wear facets and measured the volume as an expression of wear based on the LAS 20 scans, which obtained identical data. All in all, this resulted in small standard deviations so that we could differentiate the material wear of the different materials at an early stage.

As in earlier experiments [36,37], the wear behavior was inconsistent in the first 5,000 - 10,000 cycles and had a higher variability. This is a well-known effect called "running in". Therefore, the analysis of the data began at 10,000 cycles. From this point on the wear development was linear with an excellent correlation with the number of cycles $\left(R^{2}>0.98\right.$, see Fig. 2), reflecting the results of Heintze et al. [31,39], Wang et al. [41] and Matias et al [37].

When comparing the wear volume, the tested composites had approximately the same values as Tetric N Ceram Bulkfil, as tested in an earlier study [36], where at 120,000 load cycles, Tetric Ceram Bulkfil showed $0.66 \pm 0.27 \mathrm{~mm}^{3}$ whereas in the present study Tetric Ceram had $0.714 \pm 0.097 \mathrm{~mm}^{3}$ wear. The wear data of the present study are also comparable to those presented by Lendenmann and Wanner [26] for a large group of composites. The slight differences can be explained by the fact that different antagonists were used. In the present work, steatite spheres with a diameter of $6 \mathrm{~mm}$ were used, while the Ivoclar-Vivadent method used Empress antagonists in the shape of a molar cusp [26].

The linear wear development over time confirms the results of previous studies and allows formulating a wear rate for each material (Table 6). Considering that there are 4 statistical groups for the wear and the wear rate of the composites (Table 4 and 6, Fig. 2 ) the null hypothesis is rejected. The same is true for the antagonist wear (Table 5, Fig. 2).

To better understand the wear behavior of the tested composites, a plot of wear of composite vs wear of antagonists was created (Fig. 4). Some trends became visible. On the one side there is GS which forms a quite well-defined cluster with low wear and high antagonist wear. On the other side, namely the other extreme, it seems that AF forms its own group with very low antagonist wear but high composite wear. There we notice as well that for the composite wear there is a wide spread of the data points especially towards high wear. All other 
composites, with the exception of UPI Exp1 that has two "outlieres" they all form a big cluster which explains the overlap with statistical groups. Using the SEM pictures one can speculate about different wear mechanisms. AF (Fig. 5) seems to contain sharp edged filler particles up to $3 \mu \mathrm{m}$, which seem to be dislocating from the surface. In Fig. 4 even a fracture line is visible. These may explain the high wear of the material. Furthermore, AF is the only material under test that contains an ormocere as matrix, which may as well be the reason for the higher wear. On the other side, GS showed itself a scratch pattern, but "grooves" and "mountains" showed the same very small granular structure (Fig. 6). It seems that very small and hard filler particles, which are well retained to the matrix are responsible for the high wear of the antagonists as well as for the low wear of the material itself.

The UPI Exp1 and UPI Exp2 are the "Dentin" and the "Enamel" version of the same material. Regarding wear, they are in the same statistical group, which they share with TE, HR and FS. However, their structure as seen in Figs. 7 and 8 is slightly different. Both have spheroid/spherical fillers which seem to be perfectly integrated into the matrix. However, the size seems to vary slightly. The "dentin" version (UPI Exp 1) contains particles which have sizes below $4 \mu \mathrm{m}$, while the "enamel" version has not only filler particles of about the same dimension, but there are also definitely larger particles (8-10 $\mu \mathrm{m}$ and larger).This makes sense, since the light is scattered at the resin filler interface, which means that with larger filler particle less scattering and thus more translucency may be expected. UPI EXP3 (Fig. 9) seems to be based on a different approach. Most of the particles seem to be spherical, but there is a wide range of sizes. Thus, they may have been produced with spray flame pyrolysis [10] and the manufacturer has attempted to reach a maximum filler load by using different ranges of particle distributions [8]. This may be an explanation for its good wear behavior.

The different scratch patterns seen on the antagonists should correlate to the measured wear. This was only partly conclusive. The antagonists of AF seem polished (Fig. 10) while the antagonists of UPI EXP3 seem almost untouched. On the other side severe scratches could be observed on the antagonists of GS (Fig. 11) and SP. The other materials have more or less similar scratch patterns of median expression. Basically, one could expect that fillers with lower hardness would produce less scratches.

Every known wear testing device has a different approach on how to simulate wear [31]. Therefore, direct comparisons of numeric values, e.g. volumetric or vertical wear are impossible. Thus, only studies done with Willitec/Mechatronik wear testing machines can be used to perform direct comparisons with the present study. However, this is difficult as well, since there are only a few studies available which have tested the same composite materials. Lazaridou et al [33] have tested among others G-aenial Posterior, Tetric Evo Ceram and Filtek Supreme XTE. From these 3 materials only Tetric EvoCeram is the same material as the one tested in the present study. The other two are predecessors with a less developed technology as the comparable ones in the present study. For Tetric EvoCeram they report $0.33 \pm 0.052 \mathrm{~mm}^{3}$, while in the present study the same material showed $0.714 \pm 0.097 \mathrm{~mm}^{3}$ volumetric wear. This is substantially higher. The comparison between Filtek Suprem XTE and Filtec Supreme Ultra is about the same $\left(0.374 \pm 0.05 \mathrm{~mm}^{3}\right.$ vs $0.635 \pm 0.077 \mathrm{~mm}^{3}$ ) with the incertitude about the slight material difference. The discrepancy can be explained with a slight difference in the methods. Lazaridou et al were loading the samples in water at $37^{\circ} \mathrm{C}$, while in the present study the samples were thermocycled, which represents an additional stress. On the other hand, the difference between G-aenial Posterior and GS $\left(0.342 \pm 0.07 \mathrm{~mm}^{3}\right.$ vs $0.427 \pm 0.083$ $\mathrm{mm}^{3}$ ) is only minimal, which leads to the assumption that this material has been significantly improved over the years.

In the present study the wear of TE was determined to be $0.7 \mathrm{~mm}^{3}$. Heintze et al [39] have used almost the same approach as used in this study and measured for Tetric Ceram, approx. $0.6 \mathrm{~mm}^{3}$; Tetric N Ceram's wear was determined with the same method being approximately $0.5 \mathrm{~mm}^{3}$ and the one of Tetric EvoCeram was approximately $0.4 \mathrm{~mm}^{3}$ [42]. These data compare well with the values of D'Arcangelo et al. [30] which reported mean wear values for different direct composites between $0.529 \pm 0.139$ $\mathrm{mm}^{3}$ and $1.425 \pm 0.245 \mathrm{~mm}^{3}$. This is almost the same range as was found in the present study despite the fact that they used a different antagonist $(3 \mathrm{~mm} \varnothing$ zirkonium oxide).

Early composites showed definitely more wear than enamel [18], but during the continuous improvement of composite resins, the materials characteristics, especially the physical and mechanical data got improved much [5] and the wear characteristics improved as well. With this fact, other characteristics have become more important for the clinicians in the selection process for the favorite material to use. Aesthetic considerations (shade, chameleon effect), ease of application (bulk fil, thixotropy, low stickiness) or good short-term outcome (no postoperative pain) got more into the focus in the last years. Never the less wear of the tested composites is still higher than the wear of enamel [36]. Therefore, the wear behavior should, among other parameters, still be part of the evaluation process of resin composites.

\section{Conclusions}

The majority of the tested composites showed a similar wear behavior with slight differences of the measured volumetric wear. Some materials were either positioned on the high side (AF with significantly higher wear) and GS with the lowest wear. If one considers total wear, then UPI EXP 3 showed the most favorable outcome with low wear and the lowest antagonist wear.

Since these results were produced with an in vitro wear simulation, the transposition of the outcome into the clinical situation should be done with much caution. 


\section{Authors contributions}

JFR: idea, experimental design, wrote manuscript. $\mathrm{HH}$ : performed experiment, measured wear. NA: performed experiment, measured wear. CS: did statistical analysis, contributed substantially to discussion.

\section{Conflict of Interest}

All authors declare that they have no conflict of interest.

\section{Aknowledgements}

The work was supported by Ultradent Products INC. South Jordan, UTAH, USA (AGR 3309 UF, 1/15/16) and with exception of UPI Exp 1-3 the used materials were purchased by Ultradent Products Inc as well.

\section{References}

1. Bowen RL. Use of epoxy resins in restorative materials. J Dent Res. 1956;35(3):360-369. [CrossRef] [PubMed] Google Scholar Scopus

2. Bowen RL. Synthesis of a silica-resin filling material: progress report. J Dent Res. 1958;37(1):90. [CrossRef]

3. Bowen RL.Dentalfilling material comprising vinyl silanetreated fused silica and a binder consisting of the reaction product of bisphenol and glycidyl acrylate. US Patent 3066. 1962;112. Google Scholar

4. Ferracane JL. Current trends in dental composites. Crit Rev Oral Biol Med. 1995;6(4):302-318. [CrossRef] [PubMed] Google Scholar Scopus

5. Ilie N, Hickel R. Investigations on mechanical behavior of dental composites. Clin Oral Investig. 2009;13(4):427-438. [CrossRef] [PubMed] Google Scholar Scopus

6. Roulet JF. [Plastic restorations in molar region]. [Article in German]. Freie Zahnarzt. 1982;26(6):79-90.

7. Lutz F, Setcos JC, Phillips RW, Roulet JF. Dental restorative resins - types and characteristics. Dent Clin North Am 1983;27(4):697-712. [PubMed] Google Scholar Scopus

8. Roulet JF. Degradation of dental polymers. Basel, Switzerland: Karger; 1987.

9. Michl P, Rheinberger V, Ott G. [X-ray opaque dental material]. Pat. DE 3502594A1; 1985

10. Mädler L, Kammler HK, Muelller R, Pratsinis SE. Controlled synthesis of nanostructured particles by flame spray pyrolysis. J Aerosol Sci. 2002;33(2):369-389. [CrossRef] Google Scholar Scopus

11. MädlerL,KrumeichF,BurtscherP,MosznerN.Visiblytransparent \& radiopaque inorganic organic composites from flamemade mixed-oxide fillers. J Nanopart Res. 2006;8(3-4):323-333. [CrossRef] Google Scholar Scopus

12. Craig BD. Fillers and composite material with zirconia and silica nanoparticles. US Pat. No 8722759; 2014. Google Scholar

13. Willems $G$, Lambrechts $P$, Braem $M$, et al. A classification of dental composites according to their morphological and mechanical characteristics. Dent Mater. 1992;8(5):310-319. [CrossRef] [PubMed] Google Scholar Scopus

14. Bayne SC, Heymann HO, Swift EJ Jr. Update on dental composite restorations. J Am Dent Assoc. 1994;125(6):687-701. [Full text links] [PubMed] Google Scholar

15. Hickel $R$, Dasch $W$, Janda $R$, et al. New direct restorative materials. FDI Commission Project. Int Dent J. 1998;48(1):3-16. [CrossRef] [PubMed] Google Scholar Scopus

16. Ferracane JL. Resin composite - State of the art. Dent Mater 2011;27(1):29-38. [CrossRef] [PubMed] Google Scholar Scopus

17. Randolph LD, Palin WM, Leloup G, Leprince JG. Filler characteristics of modern dental resin composites and their influence on physico-mechanical properties. Dent Mater. 2016;32(12):1586-1599. [CrossRef] [PubMed] Google Scholar Scopus

18. Phillips RW, Avery DR, Mehra $\mathrm{R}$, et al. Observations on a resin or Class ॥ restorations: three year report. J Prosthet Dent. 1973;30(6):891-897. [CrossRef] [PubMed] Google Scholar Scopus

19. Lempel $\mathrm{E}$, Tóth Á, Fábián $\mathrm{T}$, et al. Retrospective evaluation of posterior direct composite restorations: 10-year findings. Dent Mater. 2015;31(2):115-122. [CrossRef] [PubMed] Google Scholar Scopus

20. Pallesen U, van Dijken JW. A randomized controlled 30 years follow up of three conventional resin composites in Class II restorations. Dent Mater. 2015;31(10):1232-1244. [CrossRef] [PubMed] Google Scholar

21. Da Rosa Rodolpho PA, Donasollo TA, Cenci MS, et al. 22-year clinical evaluation of the performance of two posterior composites with different filler characteristics. Dent Mater 2011:27(10):955-963. [CrossRef] [PubMed] Google Scholar Scopus

22. Opdam NJ, van d Sade FH, Bronkhorst E, et al. Longevity of posterior composite restorations: a systematic review and meta-analysis. J Dent Res. 2014;93(10):943-949. [Full text links] [Free PMC Article] [PubMed] Google Scholar $\underline{\text { Scopus }}$

23. Demarco FF, Corrêa MB, Censi MS, et al. Longevity of posterior composite restorations: not only a matter of materials. Dent Mater. 2012;28(1):87-101. [CrossRef] [PubMed] Google Scholar Scopus

24. Hickel R, Manhart J. Longevity of restorations in posterio teeth and reasons for failure. J Adhes Dent. 2001;3(1):45-64. PubMed] Google Scholar Scopus

25. Manhart J, Chen HY, Hamm G, Hickel R. Review of the clinical survival of direct and indirect restorations in posterior teeth of the permanent dentition. Oper Dent. 2004;29(5):481-508. [PubMed] Google Scholar Scopus

26. Lendenmann U, Wanner M. Tetric EvoCeram. Scientific Documentation. Schaan, Liechtenstein: Ivoclar Vivadent; 2011

27. Calheiros FC, Kawano Y, Stansbury JW, Braga RR Influence of radiant exposure on contraction stress, degree of conversion and mechanical properties of resin composites. Dent Mater. 2006;22(9):799-803. [CrossRef] [PubMed] Google Scholar Scopus

28. Fan PL, Schumacher RM, Azzolin K, et al. Curing-light intensity and depth of cure of resin-based composites tested according to international standards. J Am Dent Assoc. 2002;133(4):429-434; quiz 491-493. [CrossRef] [PubMed] Google Scholar Scopus

29. Ilie N, Hilton TJ, Heintze SD, et al. Academy of Denta Materials guidance - Resin composites: Part I Mechanical properties. Dent Mater. 2017;33(8):880-894. [CrossRef] [PubMed] Google Scholar Scopus

30. D'Arcangelo C, Vanini L, Rondoni GD, et al. Wear properties of a novel resin composite to human enamel and other restorative materials. Oper Dent. 2014;39(6):612-618. [CrossRef] [PubMed] Google Scholar Scopus

31. Heintze SD. How to qualify and validate wear simulation devices and methods. Dent Mater. 2006;22(8):712-734. [CrossRef] [PubMed] Google Scholar Scopus

32. Koottathape $\mathrm{N}$, Takahashi $\mathrm{H}$, Iwasaki $\mathrm{N}$, et al Quantitative wear and wear damage analysis of composite resin in vitro. J Mech Behav Biomed Mater. 2014;29:508-516. [CrossRef] [PubMed] Google Scholar Scopus

33. Lazaridou $D$, Belli $R$, Petschelt $A$, Lohbauer $U$. Are resin composites suitable replacements for amalgam? A study of two-body wear. Clin Oral Investig. 2015;19(6):1485-1492. [CrossRef] [PubMed] Google Scholar

34. Leinfelder KF, Beaudreau RW, Mazer RB. An in vitro device for predicting clinical wear. Quintessence Int. 1989;20(10):755-761. [PubMed] Google Scholar Scopus

35. Mehl C, Scheibner S, Ludwig K, Kern M. Wear of composite resin veneering materials and enamel in a chewing simulator. Dent Mater. 2007;23(11):1382-1389. [CrossRef] [PubMed] Google Scholar Scopus

36. Roulet JF, Abdulhameed N, Shen C. In vitro wear of three bulkfill composites and enamel. Stoma Edu J. 2017;4(4):248-253. [CrossRef]

37. Matias $\mathrm{P}$, Roulet JF, Abdulhameed $\mathrm{N}$, Shen C. In vitro wear of 4 different universal composites. Stoma Edu J. 2016;3(1-2):39-46.

38. Gibbs $\mathrm{CH}$, Mahan $\mathrm{PE}$, Lundeen $\mathrm{HC}$, et al. Occlusal force during chewing and swallowing as measured by sound transmission. J Prosthet Dent. 1981;46(4):443-449. [CrossRef] [PubMed] Google Scholar Scopus

39. Heintze SD, Cavalleri A, Forjanic $M$, et al. A comparison of three different methods for the quantification of the in vitro wear of dental materials. Dent Mater. 2006;22(11):1051-1062. [CrossRef] [PubMed] Google Scholar Scopus

40. Esquivel-Upshaw J, Hsu S, Abdulhameed N, et al. Volume loss 
and depth analysis using stylos profiler and laser scanner. Abstract \# 0668. IADR/AADR/CADR; March 22-25, 2017; San Francisco, CA, USA.

41. Wang $R$, Bao $S$, Liu $F$, et al. Wear behavior of light-cured resin composites with bimodal silica nanostructures as fillers. Mater Sci Eng C Mater Biol Appl. 2013;33(8):4759-4766. [CrossRef] [PubMed] Google Scholar Scopus

42. Fischer K, Lendenmann U. Tetric N-Collection. Scientific Documentation. Schaan, Liechtenstein: Ivoclar Vivadent: 2010.

\section{Jean-François ROULET}

DDS, DMD, PhD, Dr hc, Prof hc, Professor

Department of Restorative Dental Sciences, Center for Dental Biomaterials

College of Dentistry, University of Florida

Gainesville, FL, USA

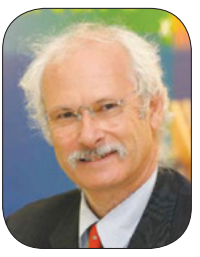

Jean-François Roulet, DDS, Dr med dent, PhD, is the former chair and current professor of the Department of Restorative Dental Sciences at the University of Florida. Professor Roulet is author/coauthor of more than 210 papers, edited/contributed to 27 textbooks and mentored more than 150 theses. He is a renowned international lecturer with over 920 appearances to date. Dr. Roulet is a member of many professional organizations, has won numerous awards, and holds four patents. He is editor of Stomatology Edu Journal. His areas of interest include minimally invasive dentistry, dental materials (ie, composites and ceramics), adhesive dentistry, esthetic dentistry, and application concepts in preventive dentistry.

\section{An universal composite is:}

Da. A composite with a universal, standard filler;

b. A composite which allows restorations with all cavity classes;

ac. A composite for high esthetic indications;

ad. A composite with high wear resistance.

\section{The materials were stressed as follows:}

a. Mechanical stress static $100 \mathrm{~N}$ for $50 \mathrm{~h}$;

b. Thermocycling for 1333 cycles from $5^{\circ} \mathrm{C}$ to $55^{\circ} \mathrm{C}$;

ac. 120,000 mechanical cycles with $50 \mathrm{~N}$ maximum force and lateral movement under load;

$\square$ d. 120,000 mechanical cycles with $50 \mathrm{~N}$ maximum force and lateral movement under load and thermocycling for 1333 cycles from $5^{\circ} \mathrm{C}$ to $55^{\circ} \mathrm{C}$.

\section{Composite wear results:}

$\square$ a. There were significant differences between the materials with G-aenial Sculpt having the least wear and UPI Exp1 and 2, Tetric EvoCeram, Filtec Supreme Ultra, and Admira Fusion being in the group with the highest wear;

$\square$ b. There were no statistical differences in the wear rate of the different composites tested;

$\square c$. The measured wear varied between $0.05 \mathrm{~mm}^{3}$ and $0.4 \mathrm{~mm}^{3}$;

$\square$ d. The standard deviation was more than $50 \%$.

\section{The antagonist wear was:}

$\square$ a. Larger than the composite wear;

b. Equal to the composite wear;

ac. Strongly correlated to the composite wear;

d. Much smaller than the composite wear with the exception of G-aenial Sculpt. 